\begin{tabular}{|c|c|c|c|c|c|}
\hline MUNIBE Antropologia-Arkeologia & $n^{\circ} 68$ & $33-47$ & DONOSTIA & 2017 & ISSN 1132-2217 • elSSN 2172-4555 \\
\hline
\end{tabular}

\title{
Cultural contact over the Strait of Gibraltar during the Middle Palaeolithic? Evaluating the visibility of cultural exchange
}

\author{
¿Contacto cultural a través del Estrecho de Gibraltar durante \\ el Paleolítico medio?. Evaluando la visibilidad del intercambio cultural
}

KEY WORDS: Mousterian, Neanderthal, cultural transmission, corridor.

PALABRAS CLAVES: Musteriense, Neanderthal, transmisión cultural, corredor.

GAKO-HITZAK: Moustier aldia, Neanderthal, kultur transmisioa, korridorea.

Yvonne TAFELMAIER ${ }^{(1)}$, Andreas PASTOORS ${ }^{(2)}$ and Gerd-Christian WENIGER ${ }^{(3)}$

\begin{abstract}
Possible contacts between hunter-gatherers of Northern Africa and Europe via the Strait of Gibraltar during the Pleistocene are still object to discussions. In the absence of significant fossil remains, debates are mainly based on similarities and differences of singular aspects of material culture. However, a theoretical framework for these discussions was lacking. The first aim of this study thus has been the development of a theoretical base. We therein included Maslow's pyramid of basic needs. The idea of our approach is that the presence or absence of so-called cultural tracers identify either contact or disparity. A large database on archaeological sites of Morocco and Southern Iberia dating between $160 \mathrm{ka}$ and $40 \mathrm{ka}$ years ago has been compiled, containing information about lithic technology and typology, lithic raw material acquisition, subsistence patterns and symbolic behaviour. We formulated three potential contact scenarios between the two regions. The presence and/ or absence of so-called cultural tracers within the data set, that covered all levels of Maslow's pyramid, led us to conclude that - based on the present archaeological and anthropological data - no contact took place between Iberian and North African populations across the Strait of Gibraltar in the given time frame.
\end{abstract}

\section{RESUMEN}

Contactos entre grupos humanos del Pleistoceno superior entre África del Norte y la Península Ibérica cruzando el Estrecho de Gibraltar están siendo objeto de debates. Por la falta de fósiles humanos significativos el debate se centra básicamente en similitudes y diferencias en la cultura material. Pero todavía falta un marco metodológico para la discusión. Este trabajo intenta la presentación de una base teórica preliminar. La pirámide de Maslow con necesidades básicas forma parte de estas reflexiones. La ausencia o presencia de marcadores culturales indica según nuestro enfoque contactos o disparidades. En un banco de datos de yacimientos arqueológicos entre 160 ka y 40 ka de Marruecos y del sur de España hemos compilado información sobre tecnología de inventarios líticos, aprovisionamiento de materias primas, patrones de asentamiento y comportamiento simbólico. Se pueden formular tres escenarios de contacto entre ambas regiones. La aplicación de marcadores culturales in relación con la pirámide entera de Maslow indica que según la información actual no se pueden demostrar contactos entre ambos continentes.

\section{LABURPENA}

Iparraldeko Afrikaren eta Iberiar penintsularen artean, Gibraltargo itsasartea zeharkatuta, Goi-pleistozenoan giza taldeen artean izan ziren harremanak eztabaidagai bihurtu dira. Gizakiaren fosil esanguratsurik ez dagoenez, eztabaidaren gai nagusia, batez ere, kultura materialean dauden antzekotasunak eta aldeak dira. Baina oraindik eztabaidarako testuinguru metodologikoa falta da. Lan honen helburua da aurretiazko oinarri teorikoa aurkeztea. Oinarrizko beharrak dituen Maslow piramidea gogoeta horien baitan dago. Gure ustez, markatzaile kulturalik ez izateak edo halakoak izateak harremanak edo desberdintasunak adierazten ditu. Marokotik eta Espainiako hegoaldetik 160 ka eta 40 ka arteko distantziara dauden aztarnategi arkeologikoetako datu-basean, inbentario litikoen teknologiari, lehengaien hornikuntzari, finkapeneko ereduei eta portaera sinbolikoari buruzko informazioa jaso dugu. Hori guztia kontuan hartuta, bi eskualdeen arteko harremanetako hiru egoera formula ditzakegu. Gaur egun eskuragarri dugun informazioaren arabera, Maslowko piramide osoarekin lotuta kultur markatzaileak aplikatzeak bi kontinente horien arteko kontaktuak ezin direla egiaztatu adierazten du.

\footnotetext{
(1) Eberhard Karls University of Tübingen. Institute of Prehistory, Early History and Medieval Archaeology. Department of Early Prehistory and Quaternary Ecology. Schloss Hohentübingen. 72070 Tübingen (Germany).yvonne.tafelmaier@uni-tuebingen.de

(2) Friedrich-Alexander-University of Erlangen-Nürnberg. Institute of Prehistory \& Early History. Kochstraße 4/18. 91054 Erlangen (Germany) andreas.pastoors@fau.de

(3) Neanderthal Museum. Talstraße 300. 40822 Mettmann (Germany). weniger@neanderthal.de
} 


\section{INTRODUCTION}

At the Strait of Gibraltar, the African and the European landmasses are separated today by only $15 \mathrm{~km}$ (Fig. 1). The strait connects the Gulf of Cádiz (Atlantic Ocean) in the West and the Alboran Sea (Mediterranean Sea) in the East. Sea level changed remarkably during the last $160 \mathrm{ka}$ (e.g. Rodríguez Vidal et al., 2004), with dropping sea levels revealing small islands in the strait (Collina-Girard, 2001). Despite this small distance, crossing the sea has been and still is a challenging endeavour. Among other factors, an eastward stream near the sea surface and a westward one running below complicate navigating.

For different time periods models of cultural contact between the southern part of the Iberian Peninsula and northern Africa via the Strait of Gibraltar have been discussed (Straus, 2001; Garcea, 2004; Santonja Gómez \& Villa, 2006; Alcaraz Castaño, 2007; Sharon, 2011; Linstädter et al., 2012; Otte, 2013; Ramos-Muñoz, 2013; Santonja Gómez, et al. 2016). According to Ramos-Muñoz the explanations behind the proposed models are based on diffusion ideas, a movement from one area of high concentration to an area of low concentration. He proposed "technological similarities are the result of the relationships and contacts within the framework of the typical mobility of hunter-gatherer societies." (Ramos-Muñoz, 2013: 35). Although the cited ideas frame the different approaches, no consistent theoretical setting for the intensive examination of possible cultural contacts between the two continents has been developed. Therefore, the present study focuses first on the design of a theoretical base for evaluating interregional interaction scenarios and second on the analysis of possible cultural contact between $40 \mathrm{ka}$ and $160 \mathrm{ka}$. At that time, Neanderthals inhabited Europe while early anatomically modern humans (early $\mathrm{AMH}$ ) are represented in Africa.

It is generally accepted that big similarities between Middle Palaeolithic inventories in the South of the Iberian Peninsula and North Africa exist (Nami \& Moser, 2010; Cortés Sánchez et al., 2012; Linstädter et al., 2012; CoIlina-Girard \& Bouzouggar, 2013; Ramos-Muñoz, 2013). These similarities concentrate on techno-typological aspects such as side-scrapers, Mousterian points and lithic reduction strategies (Ramos-Muñoz et al., 2014: 16). Ramos-Muñoz et al. (2014) interpret this observation as results from direct cultural contacts between human groups from both sides of the Strait of Gibraltar. Furthermore, analogue subsistence systems, especially the use of marine resources, are highlighted by different authors without necessarily indicating cultural context (Stringer et al., 2008; Zilhão et al., 2010; Colonese et al., 2011; Cortés Sánchez et al., 2011; Ramos-Muñoz et al., 2011).

The emergence of early $\mathrm{AMH}$ in Morocco around $160 \mathrm{ka}$ led to a more general debate about the emergence of modern human behaviour. Originally the concept was key within the model of the human revolution (Mellars et al., 2007). This was said to have taken place around $40 \mathrm{ka}$ in Europe with anatomically and behaviourally modern humans entering the European continent. However, nowadays it is clear that different facets of what has been considered to be part of modern human behaviour predates the postulated revolution around 40 ka ago. Thus, the use of marine resources as well as the production of laminar blanks and the appearance of symbolic behaviour can be traced in the archaeological record long before (McBrearty \& Brooks, 2000). The use of marine resources both occurs in Neanderthal populations in Europe (Cortés Sánchez et al., 2011) and early AMH in Africa (Jerardino \& Marean, 2010) latest around $150 \mathrm{ka}$. The manufacture of blades and bladelets likewise occurs in Middle Paleolithic and Middle stone age assemblages before 40 ka ago (Soriano et al., 2007; Pastoors, 2009; Pastoors \& Tafelmaier, 2010).

Apart from arguments based on material culture, recent palaeogenetic studies explore contact scenarios over the Strait of Gibraltar. According to a study analysing phylogenetic relationships of Crocidura russula (sensu lato) populations between the Maghreb and Western Europe a transfer of this species from Morocco to Europe via the Strait of Gibraltar has been proposed to have taken place around $60 \mathrm{ka}$ (Cosson et al., 2005). The authors hypothesized that a transport by humans was most likely. However, due to the lack of evidence the working group considered "an overestimation of population divergence time" from their molecular data (Cosson et al., 2005: 1158).

Another genetic study has been published by Sánchez-Quinto et al. (2012) wherein a potential admixture between North-African modern humans and Neanderthals has been investigated. By testing 780,000 SNPs (single nucleotide polymorphisms) of 125 individuals from different regions of Northern Africa, Sánchez-Quinto et al. (2012) discovered that these populations possess a significant number of derived alleles shared with Neanderthals in contrast to sub-Saharan Africans. Thus, they postulated that the ancestral population of North African modern humans derived from the population that first interbred with Neanderthals in the Middle East (Sanchez Quinto et al., 2012: 5). Although a possible contact via the Strait of Gibraltar is not mentioned the results do not per se exclude this scenario. However, already in 2012 Eriksson \& Manica pointed out methodological shortcomings. The use of modern human genetic data in contrast to ancient DNA could generate misleading results falsely indicating hybridization (Eriksson \& Manica, 2012: 13958). In their argumentation the ancient population substructure of Africa may explain spatial patterns of genetic overlap.

\section{METHOD}

Considerations about possible cultural contacts between the southern part of the Iberian Peninsula and northern Africa via the Strait of Gibraltar lead to the general question of human displacement. According to Gehlen, human beings differ fundamentally from other 
species with regard to the deficient configuration of the human organic nature, which creates a pressure to overcome, in the words of Gehlen (1986), to act. For him established strategies for the mitigation of the deficits are technological interventions, creation of communities and institutions wherein cultural knowledge is bundled. Based on these anthropological specifications, it seems unlikely that humans move from one place to another leaving behind all experienced survival strategies. Metaphorically speaking, when moving, humans take along their cultural baggage filled with material as well as immaterial sustenance (language, identity, religion, assumptions about social relations, reproductive capabilities, and the disposition to produce and use particular artefacts of material culture) (Fendl, 1993; Miller, 2011). Furthermore, human brain should be able to gather and manage the information necessary to reach the desired destination and a possible return.

The cited aspects of material and immaterial sustenance integrate well in Maslow's theory of motivation (Fig. 2). Although it has been developed in the 1940ies, it has not lost its relevance (Maslow 1943, 1970, 1981). The theory is set up on hierarchized categories of human needs: physiological, safety, belongingness and esteem needs are basic deficiency needs. Their lack creates a tension within us. On the higher levels Maslow placed being needs - "the desire to become more and more what one is, to become everything that one is capable of becoming" (Maslow, 1943: 383) - which may not even appear in every individual (Maslow, 1981: 102, 128f.). Physiological needs are basic: food, water, sleep, oxygen, sex, free mobility, and a manageable temperature. When any of these are in short supply, humans feel the distressing tension of hunger, thirst, fatigue, shortness of breath, sexual frustration, confinement, or the discomfort of cold or heat. Safety needs operate mainly on a psychological level. As a rule, love or belongingness need to come into play after the physiological and security drives have been satisfied. Esteem needs are of two types. There is self-esteem, which is the result of competence or mastery of tasks and likewise the attention and recognition that comes from others (Maslow, 1981).

Picking up the metaphor of the cultural baggage, which humans pack when moving from one place to another, the described content not only responds to Maslow's human deficiency needs, but also includes the being needs like identity and religion. The transmission of the mentioned anthropological reflections onto early human history can only be understood as an experiment, because past societies and ways of life have changed considerably. Against this background Lenssen-Erz and Linstädter adapted Maslow's hierarchy of needs to the conventions of prehistoric archaeology and correlated the different levels with terms in use in archaeology (Lenssen-Erz \& Linstädter, 2009) (Fig. 2).

They see their correlation as an approximation of the categories without fixed boundaries, which is not in contradiction to Maslow's theory (Maslow, 1981: 79ff.).
The described assumptions build a theoretical frame for the search of possible cultural contacts between the southern part of the Iberian Peninsula and northern Africa via the Strait of Gibraltar during the Middle Palaeolithic based on archaeological as well as anthropological findings. How can we detect traces of cultural contact? While for more recent periods a critical assessment of models for interregional interaction scenarios has taken place (Cusick, 1998; Stein, 2002), culture contact theories for Middle Palaeolithic societies are scarce. This may in parts be due to the more reduced available sources. The Encyclopædia Britannica defines cultural contact as "contact between peoples with different cultures, usually leading to change in both systems. The effects of culture contact are generally characterized under the rubric of acculturation, a term encompassing the changes in artefacts, customs, and beliefs that result from cross-cultural interaction. Voluntary acculturation, often referred to as incorporation or amalgamation, involves the free borrowing of traits or ideas from another culture. Forced acculturation can also occur, as when one group is conquered by another and must abide by the stronger group's customs." (The Editors of Encyclopædia Britannica 2016) This definition implies different scenarios for the design of the research question in the present article (Tab. 1). First, cultural contact is only possible under the precondition that both parts of the Strait of Gibraltar have been contemporaneously populated. This general precondition is fulfilled under consideration that absolute contemporaneity is not measurable in that timeframe. Between $40 \mathrm{ka}$ and 160 ka Neanderthals inhabited Europe while early AMH peopled Africa during MIS 6-3 (Garralda, 2005; Linstädter et al., 2012). The cited definition of cultural contact does not include a differentiation of the intensity of movements. This seems necessary because the archaeological visibility of continuous movements will differ distinctly from the visibility of sporadic ones. Although the archaeological visibility is an important factor, the intensity will probably not affect the content of the cultural baggage, which is filled with remains of cultural behaviour: raw material provision strategy, techno-typological behaviour, hunting strategies and symbolic objects, but it influences probably the amount of material sustenance taken out of the baggage. Other features, which document the movements from one side of the Strait of Gibraltar to the other, are taken into account, although they do not represent cultural contact: human species and refitting. Both features attest the presence of humans but not the effect of cultural behaviour. In other words, Neanderthals might have crossed the Strait, their mortal remains would have remained there, but their simple presence in Northern Africa does not pass on any information about whether cultural interaction took place or not. Similarly, refittings between artefacts found on both sides of the Strait only indicate that a person must have crossed the Strait and left part of the equipment on either side. This does nevertheless not imply that cultural exchange took place. 
The difficulty in this kind of research is the determination of tracers which indicate cultural contact between the two regions. As big parts of the Middle Palaeolithic material culture and subsistence strategies are homogeneous between Morocco and Spain, we focus on specific characteristics as valid arguments. In table 1 three scenarios that have been designed in abductive reasoning (hypothetico-deductive) (Bernbeck, 1997) are outlined.

If only one region would have been populated, interregional contact does not play any role. In that case diffusion, migration or, all movements, which are transitory in nature (nomadism or transhumance), come into question. Based on the actual anthropological findings (early $\mathrm{AMH}$ in Morocco and Neanderthals in Spain) these kinds of movements are of only minor importance.

\section{MATERIAL}

\subsection{Morocco}

Recent synthesis of age estimates from archaeological sites in Morocco confirm that the Middle Palaeolithic in North Africa chronologically falls into two distinct clusters: a recent one between 30-125 ka, starting with the beginning of MIS $5 e$, and a second older cluster reaching back to $230 \mathrm{ka}$. While the recent one is concentrated on the Temara region in Western Morocco, only Abrigo de Benzú and Ifra n'Ammar in Northern Morocco represent the older cluster (Doerschner et al., 2016). In Jebel Irhoud the first early $\mathrm{AMH}$ had been dated to around 160 ka (Smith et al., 2007) for quite a long time, however, new fossil remains and absolute dates indicate a presence of early anatomically modern humans as soon as 315 /- 34 ka years ago (Hublin et al., 2017; Richter et al., 2017). The group of Middle Palaeolithic sites in Morocco provides only a limited number of cave and open-air sites with well-defined stratigraphies (Wengler, 1997). Among them the following important sites have been included in the present study: Jebel Irhoud, Grotte des Contrebandiers (El Mnasra 1), El Mnasra, El Harhoura I (Zouhrah cave), El Harhoura II, Dar es-Soltan 1, Dar es-Soltan 2,
Chaperon Rouge 1, Mugharet el Aliya, Abrigo de Benzù, Ifri n'Ammar, Taforalt and Bizmoune (Figure 1).

\subsection{Southern Iberia}

Palaeolithic sites on the Iberian Peninsula are numerous. Most of the archaeological stratigraphies are preserved in caves and rock shelters. Nevertheless, there is likewise a substantial number of open air sites (Zilhão, 2001; Navazo et al., 2005; Navazo et al., 2008; Arrizabalaga, 2009; Jennings et al., 2011). In contrast to the high number of sites, the chronological framework for the Middle Palaeolithic is, at least in parts, fragile. Indeed, the latest/ transitional phase towards the Upper Palaeolithic has been increasingly studied within the last years (Zilhão, 2006; Wood et al., 2013; Wood et al., 2014). The time before though has gained only minor interest. The sites of the Gran Dolina/ Atapuerca, Cuesta de la Bajada and Bolomor both mark an early occurrence of the Middle Palaeolithic dating to MIS 9 respectively (Fernández Peris, 2007; Santonja et al., 2016), with Bolomor indicating human presence until MIS 5. Other sites comprise Middle Palaeolithic stratigraphies reaching from MIS 5 at least until MIS 3 such as Bajondillo (Cortés Sánchez, 2007b) or Carihuela (Vega Toscano, 1988; Carrión García et al., 1998; Fernández et al., 2007) in southern Spain. According to Salazar-García et al. (2013: 5), the Middle Palaeolithic can generally be subdivided into this early, pre-MIS 5 phase, and the classic Middle Palaeolithic sites dating to the time period from MIS 5 until MIS 3.

For quite a long time a long persistence of Neanderthals in Spain has been claimed (Finlayson et al., 2008). Nevertheless, recent studies cast serious doubts on the empiric base for late survival scenarios and rather indicate an age underestimation (Wood et al., 2013).

Due to research history, more well-studied sites are known from the northern and eastern part of the Iberian Peninsula than from central and southern Iberia. However, especially the Middle Palaeolithic occupations preserved in the caves of the Gibraltar Rock have been object to archaeological research quite early (Busk, 1864).

\begin{tabular}{|c|c|c|c|c|}
\hline Scenario & Movement & Human species & Cultural tracer & Kind of contact \\
\hline $\begin{array}{l}\text { continuous cultural } \\
\text { contact }\end{array}$ & $\begin{array}{l}\text { regular successful crossing } \\
\text { in both directions }\end{array}$ & $\begin{array}{c}\text { early AMH \& Neanderthals } \\
\text { in Morocco \& southern } \\
\text { Iberia }\end{array}$ & $\begin{array}{l}\text { homogeneity in specific } \\
\text { characteristics of Middle } \\
\text { Palaeolithic assemblages }\end{array}$ & contact with acculturation \\
\hline sporadic cultural contact & $\begin{array}{l}\text { sporadic crossing in both } \\
\text { directions }\end{array}$ & $\begin{array}{c}\text { early } \mathrm{AMH} \text { in Morocco \& } \\
\text { Neanderthals in southern } \\
\text { Iberia }\end{array}$ & $\begin{array}{c}\text { disparity in specific charac- } \\
\text { teristics of Middle Palaeo- } \\
\text { lithic assemblages, except } \\
\text { singular distinctive artefacts } \\
\text { from the reciprocal cultural } \\
\text { tradition (Southern Iberia or } \\
\text { Morocco) }\end{array}$ & contact without acculturation \\
\hline no cultural contact & no crossing & $\begin{array}{c}\text { early AMH in Morocco \& } \\
\text { Neanderthals in southern } \\
\text { Iberia }\end{array}$ & $\begin{array}{c}\text { disparity in specific } \\
\text { characteristics of Middle } \\
\text { Palaeolithic assemblages }\end{array}$ & no contact \\
\hline
\end{tabular}

Table 1: Three scenarios of possible cultural contact formulated in abductive reasoning./ Tres escenarios de posible contacto, construidos en forma abductiva. 


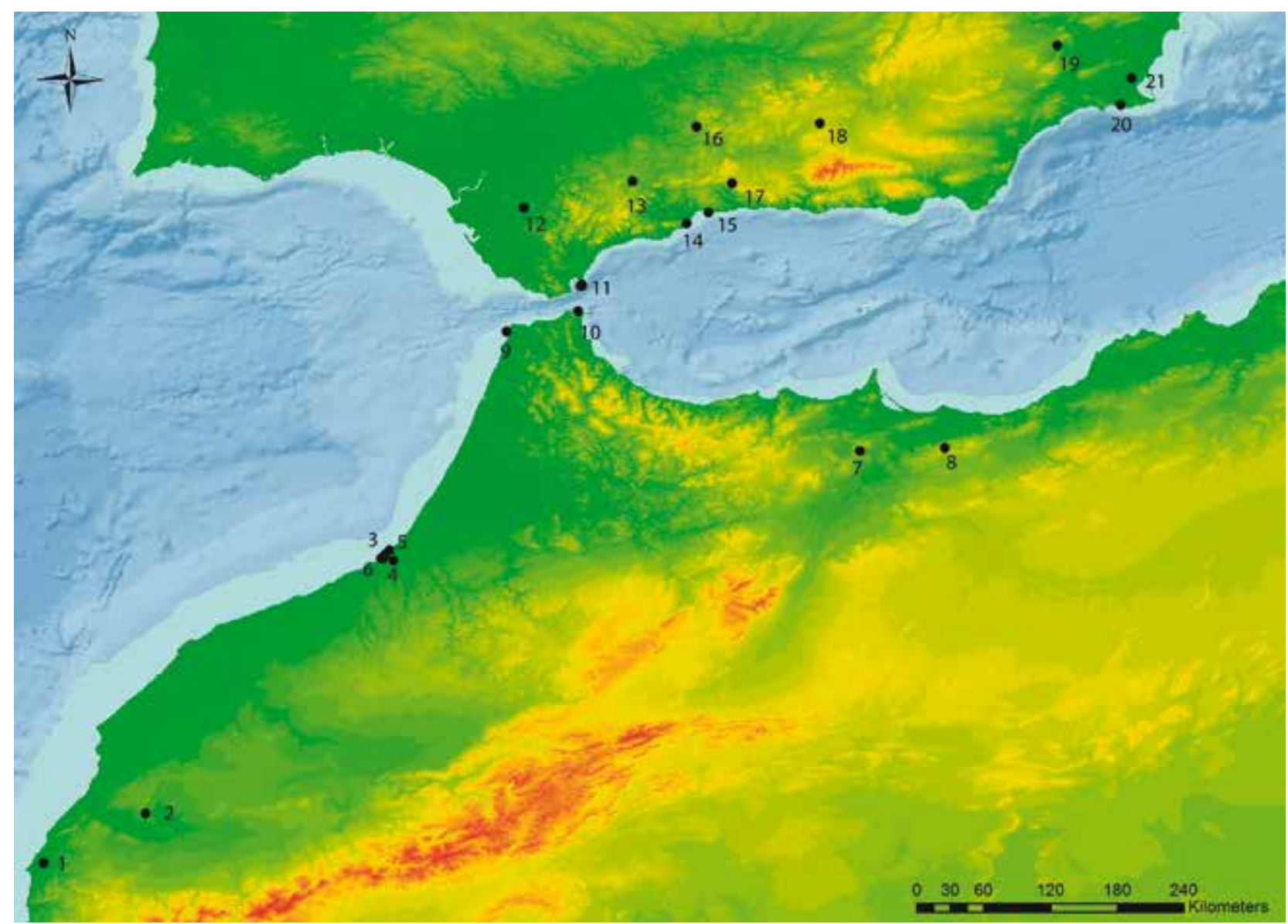

Fig. 1. Localisation of sites mentioned in the text: 1) Bizmoune, 2) Jebel Irhoud, 3) El Harhoura I \& II, 4) Dar es-Soltan 1 \& 2, 5) Chaperon Rouge 1, 6) El Mnasra \& Grotte des Contrebandiers, 7) Ifri n'Ammar, 8) Taforalt, 9) Mugharet el Aliya, 10) Abrigo de Benzù, 11) Gibraltar sites (Vanguard Cave, Ibex Cave, Beefsteak Cave, Gorham's Cave, Devil's Tower and Forbes Quarry), 12) Hiqueral de Valleja, 13) Sima de las Palomas de Teba, 14) Bajondillo, 15) La Araña sites, 16) Cueva del Ángel, 17) Boquete Zafarraya, 18) Carihuela, 19) Cueva Antón, 20) Cueva de los Aviones, 21) Sima de las Palomas (Cabezo Gordo). / Situación de los yacimientos más relevantes mencionado en el texto: 1) Bizmoune, 2) Jebel Irhoud, 3) El Harhoura I \& II, 4) Dar es-Soltan 1\& 2, 5) Chaperon Rouge 1, 6) El Mnasra \& Grotte des Contrebandiers, 7) Ifri n'Ammar, 8) Taforalt, 9) Mugharet el Aliya, 10) Abrigo de Benzù, 11) Gibraltar sites (Vanguard Cave, Ibex Cave, Beefsteak Cave, Gorham's Cave, Devil's Tower and Forbes Quarry), 12) Hiqueral de Valleja, 13) Sima de las Palomas de Teba, 14) Bajondillo, 15) La Araña sites, 16) Cueva del Ángel, 17) Boquete Zafarraya, 18) Carihuela, 19) Cueva Antón, 20) Cueva de los Aviones, 21) Sima de las Palomas (Cabezo Gordo).

Due to their strategic location and likewise rich archaeological record, they are of special interest here. The number of well-studied sites in southern Spain is not that high. Recent excavations at several places such as Las Palomas de Teba and Higueral de Motillas (e.g. Torres Navas et al., 2012; Kehl et al., 2016) will surely shed more light on the Middle Palaeolithic of the region in the future. For this study, apart from the Gibraltar sites (Vanguard Cave, Beefsteak cave, Gorham's cave, Ibex cave) information derives mainly from the cave of Zafarraya, Bajondillo, Carihuela, Las Palomas de Teba, Higueral de Sierra Valleja and Complejo del Humo (Fig. 1). All of them can be attributed to the MIS 5 to MIS 3 site cluster.

\section{RESULTS}

\subsection{Human species}

Morocco - Apart from unstratified findings, human remains originate from six different sites in Morocco: Je- bel Irhoud (Hublin et al., 1987, 2017), Grotte des Contrebandiers (Nespoulet et al., 2008), El Mnasra (Stoetzel et al., 2014), El Harhoura I (Monchot \& Aouraghe, 2009), El Harhoura II (Stoetzel et al., 2014) and Dar es-Soltan 2 (Nespoulet et al., 2008). Combined with the presence of Middle Palaeolithic material remains, all morphological evidence suggests only early $\mathrm{AMH}$ are present in this part of North Africa (Foley \& Lahr, 1997; Campmas et al., 2016).

Spain - The fossil record of the Iberian Peninsula for the considered time frame is quite rich (Dodge, 2012). There are more than 30 sites that yielded anthropological remains (Garralda et al., 2014). All these finds are exclusively assigned to Neanderthals. From a chronological point of view, the bulk of sites date to MIS 3, while only some remains derive from MIS 5 and MIS 4 (Garralda, 2005). The stratigraphic context for some assemblages can be described as substantial (Walker et al., 2008; Lalueza Fox et al., 2011; Walker et al., 2012), 
for others rather weak (Garcia Sanchez et al. 1994). An intentional burial may be evidenced by the articulated skeletons found at Palomas del Cabezo Gordo (Walker et al., 2012). In southernmost Iberia the most important sites with Neanderthal remains are Forbes' Quarry and Devil's Tower (Gibraltar), Carihuela (Carrión García, 1992) and Zafarraya Cave in Málaga (Barroso Ruiz \& Hublin, 1994).

The Iberian Neanderthal remains are mostly associated with Mousterian, i.e. flake based Middle Palaeolithic assemblages. However, some finds are perceived as evidence for a late presence of Neanderthals contemporary to Aurignacian assemblages in Northern Iberia (Jennings et al., 2011). This has been claimed for Gibraltar (Finlayson et al., 2008) or Zafarraya (Fontugne et al. 1995). As already pointed out above, late survival scenarios seem though to be the result of inaccurate age determinations (Wood et al., 2013).

\subsection{Cultural tracers}

Data on technological, specific techno-typological and symbolic behaviour, as well as general subsistence patterns (e.g. resource exploitation) have been compiled from Middle Palaeolithic sites on both sides of the Strait of Gibraltar. Based on this data collection specific characteristics, which may serve as valid cultural tracer for possible cultural contact, shall be detected. Due to different states of publication, the compilation of data is certainly incomplete. Nevertheless, the data base is regarded as substantial with respect to the chosen parameters and shall give insight into possible interregional contact between the southern part of the Iberian Peninsula and northern Africa via the Strait of Gibraltar.

\subsubsection{Lithic technology}

Morocco - In the Middle Palaeolithic of Morocco, different methods of surface conceptions, including Levallois recurrent uni-, bidirectional and centripetal methods dominate. Furthermore, discoid cores and opportunistically-reduced ones such as Kombewa cores are common. An interesting aspect is the presence of micro-Levallois cores, which might indicate a possible cultural tracer, as it marks a speciality for Moroccan Middle Palaeolithic core configuration [e.g. (Bouzouggar, 1997; Bouzouggar et al. 2002; Nespoulet et al., 2008; Barton \& d'Errico, 2012; Bouzouggar \& Barton, 2012; Dibble et al., 2012; Scerri 2013a, 2013b; Scerri et al., 2014). In general, lithic technology is described to be very flexible (e.g., Nespoulet et al., 2008; Bouzouggar \& Barton, 2012; Spinapolice \& Garcea, 2014; Campmas et al., 2016). According to Clark's system (1969), Ramos-Muñoz (2013) classified this bundle of technological features as Mode III technology characterised by the presence of prepared core industries.

Southern Iberia - Compared to other European regions, the techno-typological variation within the Middle
Palaeolithic lithic record of the Iberian Peninsula is rather low (Torre et al., 2013). The associated industries are mainly flake-based, bifacial or unifacial surface-shaping is almost absent. Therefore, the term Mousterian is commonly used in the descriptions of the archaeological assemblages from the Iberian Peninsula. Bifacial technology is mainly constrained, per definition, to the Acheulean which is said to be a technological entity besides the Middle Palaeolithic (or Mousterian) respectively (Santonja Gómez et al., 2016). Acheulean sites are mainly open-air locations, with sometimes complex taphonomic situations. In the latest phase of the Middle Pleistocene, Acheulean and Middle Palaeolithic assemblages are said to coexist for a substantial period of time (Santonja Gómez et al., 2016). The Cueva del Ángel (Cordoba), probably dating from MIS 11 to MIS 5 (Barroso Ruiz et al., 2012) shows bifacial technology in combination with the production of flakes from opportunistic and discoid cores. The presence of bifaces led to the assignment to the Acheulean (Botella Ortega et al., 2006; Barroso Ruiz et al., 2012).

The Middle Palaeolithic lithic record has been described mainly from a typological perspective (Torre et al., 2013). Only within the past 20 years, technological studies have been conducted. However, lots of studies concerned with the Middle Palaeolithic, focus on the time of the Middle- to Upper Palaeolithic transition while earlier time slices are neglected (Torre et al., 2013). From a technological point of view, within Southern Iberian Mousterian assemblages typical Middle Palaeolithic reduction strategies are represented. General chronological trends are, at least according to the current stage of knowledge, not conceivable (Torre et al., 2013: 327). Differences are rather of quantitative than of qualitative nature. The Levallois concept is present with its different production methods (preferential, recurrent uni-, bidirectional and centripetal) as well as the discoid and the Kombewa concept. At Bajondillo, already mentioned above, the Levallois concept as well as the discoid concept are present throughout the complete sequence. These concepts are complemented by the application of the Kombewa method as well as rather opportunistic production methods (Cortés Sánchez, 2007a). At Zafarraya, the La Araña sites (Cueva del Humo, Abrigo 3 and Abrigo 4) (Fernández et al., 2001), the different caves in the Gibraltar Rock (Shipton et al., 2013) and Carihuela the Levallois production is likewise attested. The assemblages of the Middle Palaeolithic layers $V$ to $X$ of Higueral de Sierra Valleja are said to be quite variable with respect to applied reduction strategies as well as raw material selection (Jennings et al., 2009). However, the Levallois concept could be identified within layers $\mathrm{VI}$ and $\mathrm{V}$ and the discoid concept was present throughout the whole sequence (Jennings et al., 2009: 5). At Sima de las Palomas de Teba the Levallois and the Kombewa concept are represented at least in units 6, 9 \& 10 (Kehl et al., 2016). 


\subsubsection{Formal tools}

Morocco - Particularities in the sample of Moroccan Middle Palaeolithic formal tools are some bifacial types, but especially tanged tools. The bifacial component of Moroccan Middle Palaeolithic collections seems to be very reduced: apart from single bifaces, most bifacial formal tools are bifacial foliated ones, which remind feuille de laurier and pointes à face plane (Texier, 1986; Bouzouggar et al., 2002; Nespoulet et al., 2008; Barton et al., 2009; Richter et al., 2010; Dibble et al., 2012; Stoetzel et al., 2014; Kuhn et al., 2015; Ramos-Muñoz et al., 2016; Campmas et al., 2016). Interestingly, Bouzouggar et al. (2002) mentioned the presence of 15 Blattschaber from level 6base in Mugharet el Aliya. This formal tool type is a singularity in the Moroccan Middle Palaeolithic and a type fossil for the European Micoquian (Floss, 2013).

Tanged tools comprise a panoply of simple blanks with unmodified edges as well as retouched tools such as points and side-scrapers. The pedunculates were prepared through a bifacial thinning of the proximal end (Tixier, 1967). Based on a technological analysis by lovita, most important parts of the tanged tools are the edge and the tang, which were preserved during the process of reshaping (lovita, 2011). The results suggest, that not only the initial product, but also the reshaped forms could be hafted and indicate a long life of usage (Campmas et al., 2016). Analyses of use-wear traces on tanged tools from Taforalt indicate the cutting of hard and soft animals parts (Bouzouggar \& Barton, 2012). Single tanged points show distal cone fractures pointing to the fact that they were probably more often used for butchering activities than as projectiles (Bouzouggar \& Barton, 2012).

Southern Iberia - In contrast to the Moroccan record, tanged pieces are lacking in Southern Iberia. It seems as if this special technological feature is restrained to Northern Africa and was not communicated to the European continent.

Similarly, the presence of bifacially and unifacially surface-shaped pieces within Middle Palaeolithic contexts is rare. Within the Bajondillo sequence for instance, reaching from MIS 6 to MIS 3, only in level 17 two bifacial artefacts are present (Cortés Sánchez, 2007a). Within all other assemblages of the sequence, surface shaping is lacking completely (Cortés Sánchez 2007a). The cave site of Ángel in Córdoba, already mentioned above, may indicate the presence of bifacial surface shaping up to MIS 5 (Barroso Ruiz et al., 2012). In general, Mousterian assemblages are characterized by modified flakes such as different types of side-scrapers, notches and denticulates (Ramos-Fernandéz et al., 2003; Barroso Ruiz \& Lumley, 2006; Cortés Sánchez, 2007a; Shipton et al., 2013). Mueller-Wille (1983 cited after Barton, 1988) proposed a variability of Iberian Middle Paleolithic assemblages along the proportion of side-scrapers on the one hand and denticulates on the other hand as well as "the relative frequencies of single and multiple edged sidescrapers" (Barton, 1988: 13). However, further analysis of this observation is lacking.

\subsubsection{Raw material provision strategy}

Morocco - The raw material provision strategies as documented in the Moroccan Middle Palaeolithic inventories follow the same flexibility as already described in the context of lithic technology. Mostly local raw material with diverse forms and qualities were collected and integrated in the lithic reduction strategies (Bouzouggar et al., 2002). The list encompasses flint, quartzite, quartz, limestone, sandstone, chalcedony, lava, basalt, diorite, radiolarite and chert (Hublin et al., 1987; Barton et al., 2009; Richter et al., 2010; Dibble et al., 2012; Campmas et al., 2015; Ramos-Muñoz et al., 2016; Campmas et al., 2016). Some non-local raw material was additionally identified. It originates from distances of 20 up to $50 \mathrm{~km}$ and points into Southern directions towards the catchment basin of Wadi Bouregreg (Barton et al., 2009; Campmas et al., 2016).

Southern Iberia - For the Middle Palaeolithic of the Iberian Peninsula in general, de la Torre et al. (2013,: 330) do not see any diachronic trends as for instance a steady increase of exotic raw materials throughout time. Raw material acquisition in the Middle Palaeolithic of Southern Spain is mainly of local character (Simón VaIlejo \& Cortés Sánchez, 2007; Jennings et al., 2009; Jennings et al., 2011; Shipton et al., 2013; Kehl et al., 2016). However, at some sites the spectrum of represented raw material indicates transport over regional and supra-regional distances (Jennings et al., 2009, Shipton et al., 2013). Chert and flint of high quality are present in the vicinity of many sites in Andalusia (Simón Vallejo \& Cortés Sánchez, 2007; Shipton et al., 2013; Kehl et al., 2016). The spectrum of used raw material comprises different varieties of chert, flint, radiolarite, limestone, and quartzite (Simón Vallejo \& Cortés Sánchez, 2007; Jennings et al., 2009; Shipton et al., 2013; Kehl et al., 2016).

\subsubsection{Subsistence strategies}

Morocco - According to Stoetzel et al. (2014) during Moroccan Middle Palaeolithic humans generally made use of all available resources in the immediate surrounding. In coastal regions large ungulates (Gazella sp., Bovinae, Equidae, Suidae) and tortoises were consumed (Steele \& Álvarez Fernández, 2011; Campmas et al., 2016). A special feature of these coastal regions is the attested consumption of marine shellfish at Grotte des Contrebandiers (Dibble et al., 2012), El Mnasra (Campmas et al., 2015; Campmas et al., 2016), El Harhoura I (Stoetzel et al., 2014), El Harhoura II (Stoetzel et al., 2014), Dar es-Soltan 1 (Stoetzel et al., 2014), Mugharet el Aliya (Campmas et al., 2016) and Abrigo de Benzù (Ramos-Muñoz et al., 2016). The most abundant species are mussels, oysters, barnacles and limpets 
(Steele \& Alvarez-Fernandez, 2011, 2012). However, in some sites (El Mnasra, El Harhoura II and Abrigo de Benzù) marine mollusc consumption was also documented (Campmas et al., 2016).

Southern Iberia - Subsistence patterns in the Southern Iberian Middle Palaeolithic reflect the behavioural variability described for Neanderthals in other environments (Patou Mathis, 2000). Middle to large sized herbivores such as Equus sp., Cervus el., Bos/Bison, Sus scrofa or Capra sp./ Capra ibex have been frequently consumed (Barroso Ruiz \& Lumley, 2006; Jennings et al., 2009; Currant et al., 2012). Moreover, small game also played a substantial role within Neanderthal's diet. For Gorham's cave and Vanguard cave, the large amounts of rabbits and birds within the Mousterian assemblages are interpreted as remains of hunting activities (Brown et al., 2011). Similar evidence for lagomorph consumption is found farther north, outside the here studied area, in the Cueva del Bolomor at the Mediterranean coast (Sanchis Serra \& Fernández Peris, 2011). In addition to terrestrial species, marine resources are part of Neanderthals' diet in Southern Spain. Both, shellfish as well as sea mammals have been consumed. Evidence for shellfish gathering comes from Bajondillo, where remains are numerous within layers 19 (MIS 6), 18 (MIS 5), and 17 (MIS 4) (Cortés Sánchez et al., 2011). The results of this study indicate the use of marine resources similarly early as at Pinncale Point
(South Africa) (Jerardino \& Marean, 2010). Correspondingly, at Vanguard cave (Gibraltar), though with a MIS 3 chronology, mollusc consumption is indicated with Mytilus galloprovincialis dominating the assemblage of Unit B. At least 10 intertidal mollusc species have been identified for the Mousterian of Gorham's cave as well as shallow-water soft-sediment species such as Venus shell (Callista chione) or spiny scallop (Spondylus gaederopus) (Brown et al., 2011). Moreover, sea mammals such as dolphins (Delphinus delphis, Tursiops truncatus) and monk seals (Monachus monachus) have been intentionally butchered as suggested by cut marks on two bones deriving from units $\mathrm{C}$ and $\mathrm{D}$ of Vanguard cave (Stringer et al., 2008). Additionally, bluefin tuna (Thunnus thynnus) and different sea urchins (Paracentrotus lividus) belong to the prey taxa of the same site (Brown et al., 2011: 261).

\subsubsection{Symbolic objects}

Morocco - Of special importance for the emergence of modern social behaviour is the appearance of explicitly symbolic objects (d'Errico et al., 2009; Vanhaeren et al., 2013). In Moroccan Middle Palaeolithic contexts, ornaments such as shell beads (Nassarius sp.) have been recorded at seven different sites: Grotte des Contrebandiers (Dibble et al. 2012), El Mnasra (Campmas et al., 2015, Campmas et al., 2016), El Har-

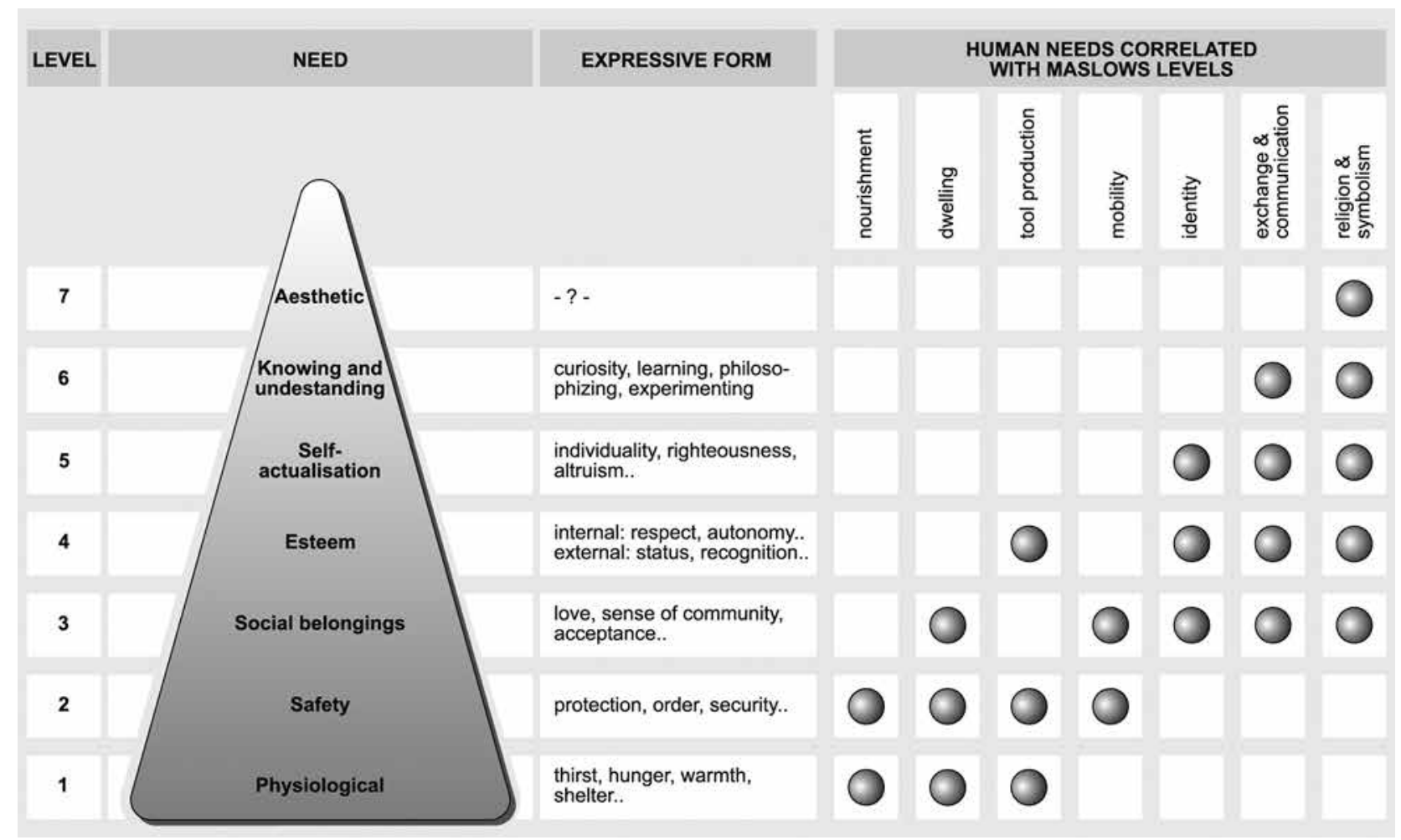

Fig. 2. Human needs as defined by Lenssen-Erz and Linstädter (2009), correlated with levels of Maslow's Pyramid of human needs (Maslow 1970). / Necesidades humanas definidas según Lenssen-Erz y Linstädter (2009), relacionada con niveles de la pirámide entera de Maslow (1970). 
houra II (Stoetzel et al., 2014), Dar es-Soltan 1 (Stoetzel et al., 2014), Ifri n'Ammar (Eiwanger et al., 2012), Taforalt (Bouzouggar et al., 2007) and Bizmoune (Kuhn et al., 2015). The use of personal ornaments is limited to the recent cluster of Middle Palaeolithic sites between 30-125 ka (d'Errico et al., 2009). Analysis of shells from Ifri n'Ammar, Grotte des Contrebandiers and Taforalt indicate, that they were transported over some distances (up to $60 \mathrm{~km}$ ) to these sites, because they do not derive from the local sources (d'Errico et al., 2009). According to the authors of the cited study, the shells have been collected already dead on the shore. They provide perforation on the dorsal face. This perforation is mostly the result of natural factors - gastropod predators, beach gravel and other injuries. Their presence in Middle Palaeolithic sites however, is "not the result of a random collection of dead shells on a shoreline." (d'Errico et al., 2009: 16053), because large proportion of unperforated shells are missing. Singular shells show undoubtedly striations resulting from anthropogenic perforation activities (Taforalt - (d’Errico et al., 2009: 16054).

Furthermore, apart from shells, red pigments were also interpreted as symbolic objects (d'Errico et al., 2009). They are present at four sites: El Mnasra (Stoetzel et al., 2014), Dar es-Soltan 1 (Barton et al., 2009), Ifri n'Ammar (Nami \& Moser, 2010) and Taforalt (Bouzouggar et al., 2007). In all cases raw material analyses indicate the use of hematite.

Southern Iberia - In contrast to the last century, when Neanderthals were mainly regarded as cognitively inferior to contemporaneous early $\mathrm{AMH}$, there is now evidence for Neanderthals' capability of symbolic behaviour (d'Errico et al., 1998; White, 2001; Peresani et al., 2011). However, the number of sites on the Iberian Peninsula and especially in Southern Spain and Gibraltar is low. In contrast to the numerous sites with shell beads reported from Morocco, personal ornaments are scarce. There are only two sites on the Iberian Peninsula showing reliable evidence of shells as adornments. At Cueva Antón and Cueva de los Aviones (Murcia/ located outside the study area) some marine shells show both intentional perforation as well as remnants of red, yellow and black pigments (Zilhão et al., 2010). Originally dated to around 50 ka (Zilhão et al., 2010) an older chronology for Antón has been proposed recently (Zilhão et al., 2016).

Apart from personal ornaments, evidence for symbolic behaviour comes from Gorham's Cave, where a rock engraving has been discovered (Rodríguez Vidal et al., 2014). According to the authors the engraving has been covered by intact Mousterian sediments giving a terminus ante quem of around $39 \mathrm{ka}$ (Rodríguez Vidal et al., 2014).

\section{DISCUSSION \& CONCLUSION}

With respect to the above presented data a quite diverse picture of the two studied regions at the given time frame emerges. In the following, we examine the corpus for valid cultural tracers on both sides of the Strait of Gibraltar (Table 2). There are linking as well as separating facets between the two areas. Afterwards we will evaluate and discuss the significance of the presence and absence of the different tracers for the raised issue.

With regard to the represented human species it can be said that, at least to the current state of knowledge, anthropological remains of Neanderthals are lacking completely in Northern Africa. Likewise, early $\mathrm{AMH}$ fossils dating prior to the 40 ka boundary are absent in Southern Iberia (and Europe in general). Thus, from that perspective data suggest that neither early $\mathrm{AMH}$ did cross the Strait of Gibraltar from Morocco to Spain in the studied time frame, nor Neanderthals vice versa.

Drawing our attention to the identified technological characteristics of lithic production it comes out that broad similarities exist between the two studied areas. The spectrum of core reduction strategies in Morocco and Spain comprises the majority of known concepts and methods for lithic production (see Delagnes \& Meignen, 2006). To some extent, blank production is quite similar with the presence of the Levallois and the discoid concept. Moreover, more flexible strategies have been applied of which the most standardized is the Kombewa concept. But also other rather opportunistically reduced flake cores exist in both studied regions. Apart from the micro-Levallois cores, no reduction strategy attracts attention. These micro-Levallois cores are a characteristic of the North African assemblages. In southern Spain and Gibraltar these remains seem to be absent. However, this may result from the missing focus to identify micro-Levallois objects. In Portugal, micro-Levallois cores have been identified in Mousterian assemblages such is the case at Gruta da Figueira Brava (Zilhão, 2012: 77). The same is true for Late Middle Palaeolithic sites farther north such as Quebrada, Axlor or Roca dels Bous (Mora Torcal et al., 2004; Ríos Garaizar et al., 2015). Rios-Garaizar et al. (2015) state that the search for small

\begin{tabular}{|l|c|c|}
\hline & Morocco & Southern Iberia \\
\hline Lithic technology & no specifics & no specifics \\
\hline Formal tools & bifacial surface-shaping \& tanged pieces & no specifics \\
\hline Raw material provision strategy & no specifics & no specifics \\
\hline Subsistence strategy & no specifics & no specifics \\
\hline Symbolic objects & shell beads, pigments & rock engraving \\
\hline
\end{tabular}

Table 2: Specific characteristics of Middle Paleolithic assemblages interpreted as cultural tracers for possible contact scenarios between Morocco and Iberia. / Características específicas de los inventarios del Paleolítico medio interpretado como indicadores culturales de escenarios de contacto entre Marruecos y el sur de la Península Ibérica. 
products is a characteristic for the late Middle Paleolithic of the Iberian Peninsula. Some sites in France, but likewise in Central and Eastern Europe yield evidence for micro-Levallois or micro-tool production in general dating to the Middle as well as to the Upper Pleistocene (Burdukiewicz \& Ronen, 2003).

In the view of represented tool types, the in general most common Middle Paleolithic formal tool forms are attested in both regions. From the perspective of this feature, both sides of the Strait are comparable. Various forms of side-scrapers, denticulates and less standardized modified flakes are part of the Middle Paleolithic tool kits in both regions. Apart from that, North African assemblages differ from Southern Iberian ones in the regular presence of bifacial surface-shaping. Moreover, tanged pieces are restrained to Moroccan assemblages and completely absent in Southern Iberia. In our approach these specific characteristics represent cultural tracer for the analysis of possible contacts between Morocco and Spain.

Raw material procurement is likewise a linking factor between both regions. Patterns are quite similar with local acquisition being the dominant strategy. However, in both regions more flexible patterns are attested in case it was necessary. No exclusive focus on specific quality or format can be determined. High quality flint and chert are mainly used, but other raw materials such as limestone or quartzite have likewise been utilized. Although general patterns are alike, no direct link between the two regions could be found. There is no evidence of a raw material unit (RMU), that has crossed the Strait. To the contrary, in Morocco the prevailing direction of exploited raw material sources points southwards.

Similar to lithic raw material procurement, faunal exploitation patterns on both sides are quite alike. In both regions, middle to large sized herbivores part of the respective ecosystems have been consumed. Due to the location close to the sea, in both areas marine resource exploitation played an important role and is regularly attested. The consumption of marine mammals as indicated in Southern Iberia is missing in Morocco so far.

Symbolic objects show a quite distinct distribution and more separating than linking features. Shell beads, recurrently present in North African assemblages, are completely absent in Southern Iberian Middle Paleolithic ones. Only two sites in Spain, farther north, yielded evidence for perforated shells as ornaments. The use of pigments, apart from the two sites aforementioned, is likewise constrained to Moroccan Middle Paleolithic sites. To the contrary, the engraving is a singular feature of Spain and no comparable evidence is attested in North Africa.

The studied features suggest a certain comparability between Middle Palaeolithic sites in Morocco and Spain. However, the similarities comprise only general Middle Palaeolithic strategies. Specific characteristics are documented either in Morocco or Spain and separate the material culture on both sides. Taking up again the metaphor of the cultural baggage, which humans pack when moving from one place to another, we assume that it is unlikely that they leave all experienced survival strategies home. Within Maslow's pyramid all features, describing the different facets of human's way of life, are represented. The fact, that the here studied characteristics cover all levels of the pyramid (Lenssen-Erz \& Linstädter, 2009), guarantees a solid data base to identify and evaluate different contact scenarios. Technology, formal tools, raw material provisioning and subsistence strategy represent mostly physiological and safety needs. Furthermore, formal tools cover esteem-needs. Social belongings, esteem, self-actualization, knowing and understanding and aesthetic-needs are fulfilled by symbolic objects. We already summarized in table 2 that the linking features such as similarities in technology, typology and subsistence patterns are common features of Middle Paleolithic occupations. These similarities do not require continuous contact and information transfer between the acting individuals. However, these findings do likewise not contradict models of interregional interaction.

Evaluating the aforementioned three scenarios (continuous, sporadic or no contact) we conclude that continuous cultural contact is absolutely excluded. Neither the expectation, that early $\mathrm{AMH}$ and Neanderthals are present in both regions is fulfilled, nor the compilation of possible cultural tracers for interregional contact supports this scenario. We would expect, that symbolic behaviour as well as the technology of tanging, which pertains in Morocco over a remarkable time span, occurred in Southern Iberia likewise. The fact that it does not, argues in favour of separate developments in both regions.

Although the anthropological findings do not challenge the scenario of sporadic contacts, we conclude that infrequent interregional interaction has most probably not taken place. Singular distinctive artefacts, evidencing reciprocal cultural transmission are not documented in the archaeological assemblages. Admittedly, the visibility of this scenario is limited as only a small amount of the potential archaeological record is at our disposition. Moreover, singular artefacts devote any archaeological context are difficult to detect. Additionally, it has to be born in mind that due to sea level changes and nowadays considerable high sea level, many coastal sites in Southern Iberia certainly have been lost. With respect to this second scenario this observation might be of interest. Most probably these objects would have occurred closest to North Africa and in fewer cases at high distances from their source region.

Within the scenario of regular contact, where we assume changes in the local subsistence systems the loss of sites is not important. Cultural traits would not have remained restricted to the coastal sites but likewise occurred farther inland (as is the case in Morocco e.g.).

Finally, anthropological as well as archaeological remains argue against the existence of cultural contacts 
between Morocco and Spain. Cultural tracers such as the technological concept of tanging, bifacial surface-shaping and the regular production of shell beads is solely documented in Morocco and did not cross the Strait of Gibraltar. Similarities in technological behaviour such as the application of similar concepts of blank production is interpreted as parallel co-evolution rather than the result of interregional contact over the Strait. This Middle Palaeolithic behaviour is characteristic for both Homo sapiens sapiens and Homo sapiens neanderthalensis in large parts of the Old World over a considerable time frame. Therefore, this finding cannot be taken as evidence for continuous interregional contact. Correspondingly, subsistence behaviour rather is driven by the natural environments, i.e. the closeness to the sea, than by reciprocal innovation transfer. Exploitation of marine resources is documented in South Africa as early as MIS 6 and seems to be a common feature of Middle Stone Age and Middle Paleolithic behaviour (Marean et al., 2007; Marean, 2011; Will et al., 2013).

Although it seems tempting to imagine that humans living at the coast within sight of each other were curious to attempt journeys over the sea, the archaeological record does not support continuous interregional interaction.

\section{ACKNOWLEDGEMENTS}

This article was prepared within the frame of the Deutsche Forschungsgemeinschaft supported research project CRC 806 ,Our way to Europe'. Further thanks are due to the Moroccan and Spanish colleagues, especially Abdeslam Mikdad and José Ramos-Muñoz for their hospitality, lively discussions and exchange of information. Jörg Linstädter and Alessandro Poti likewise shared with us their knowledge and data about the North African Palaeolithic. Thanks also to two anonymous reviewers for their fruitful comments on the first draft of this paper.

\section{REFERENCES}

Alcaraz Castaño, M., 2007. El Ateriense del Norte de África y el Solutrense peninsular: ¿contactos transgibraltareños en el Pleistoceno Superior? Munibe Antropologia-Arkeologia 58, 101-126.

Arrizabalaga, Á., 2009. The Middle to Upper Paleolithic Transition on the Basque Crossroads: Main Sites, Key Issues. Mitteilungen der Gesellschaft für Urgeschichte 18, 39-70.

Barroso Ruiz, C., Botella Ortega, D., Caparrós, M., 2012. La cueva del Ángel (Lucena, Córdoba) un hábitat achelense de cazadores en Andalucía. Revista de Prehistoria de Andalucía 3, 27-56.

Barroso Ruiz, C., Hublin, J.J., 1994. The late Neanderthal site of Zafarraya (Andalucía, Spain). In: Gibraltar during the Quaternary, edited by AEQUA, 61-70. AEQUA Monografías 2.

Barroso Ruiz, C., de Lumley, H. (Eds.), 2006. La grotte du Boquete de Zafarraya: Málaga, Andalousie / sous la direction de Cecilio Barroso Ruiz et Henry de Lumley / [Sevilla]: Junta de Andalucía, Consejeria de cultura, DL 2006. Junta de Andalucía, Consejería de Cultura, Sevilla.
Barton, C.M., 1988. Lithic variability and middle Paleolithic behavior: New evidence from the Iberian Peninsula. B.A.R., Oxford. BAR international series 408.

Barton, N.E., Bouzouggar, A., Collcutt, S.N., Schwenninger, J.L., Clark-Balzan, L., 2009. OSL dating of the Aterian levels at Dar es-Soltan I (Rabat, Morocco) and implications for the dispersal of modern Homo sapiens. Quaternary Science Reviews 28 (19-20), 1914-1931.

Barton, N.E., d'Errico, F., 2012. North African origins of symbolically mediated behaviour and the Aterian. In: Scott, E. (Ed.), Origins of Human Innovation and Creativity, 23-34. Elsevier. Developments in Quaternary Sciences 16.

Bernbeck, R., 1997. Theorien in der Archäologie. UTB für Wissenschaft 1964. Francke, Tübingen.

Botella Ortega, D., Barroso Ruiz, C., Riquelme Cantal, J.A., Abdessadok, S., Caparrós, M., Verdú Bermejo, L., Monge Gómez, G., García Solano, J.A., 2006. La Cueva del Ángel (Lucena, Córdoba), a site of the Middle and Early Upper Pleistocene in the South of the Iberian Peninsula. Trabajos de Prehistoria 63 (2), 153-65. doi:10.3989/tp.2006.v63.i2.22.

Bouzouggar, A., 1997. Matières premières, processus de fabrication et de gestion des supports d'outils dans la séquence atérienne de la grotte d'El Mnasra I (ancienne grotte des Contrebandiers) à Témara (Maroc). Thèse de Doctorat, Université Bordeaux I.

Bouzouggar, A., Barton, N.E., 2012. The Identity and Timing of the Aterian in Morocco. In: Hublin, J.J., McPherron, Sh. P. (Eds.), Modern origins: A North African perspective, 93-105. Vertebrate paleobiology and paleoanthropology series. Springer, Dordrecht

Bouzouggar, A., Barton, N.E., Vanhaeren, M., d'Errico, F., CoIlcutt, S.N., Higham, T.F.G., Hodge, E., Parfitt, S., Rhodes, E., Schwenninger, J.L., Stringer, C., Turner, E., Ward, S., Moutmir, A., Stambouli, A., 2007. 82000-year-old shell beads from North Africa and implications for the origins of modern human behaviour. Proceedings of the National Academy of Sciences 104, 9964-9968.

Bouzouggar, A., Kozlowski, J.K., Otte, M., 2002. Etude des ensembles lithiques atériens de la grotte d'El Aliya à Tanger (Maroc). L'Anthropologie 106, 207-48.

Brown, K., Fa, D.A., Finlayson, G., Finlayson, C., 2011. SmaII Game and Marine Resource Exploitation by Neanderthals: The Evidence from Gibraltar. In: Bicho, N.F., Haws, J.A., Davis, L.G. (Eds.), Trekking the Shore, 247-72. Springer, New York.

Burdukiewicz, J.M., Ronen, A., 2003. Lower Palaeolithic Small Tools in Europe and Levant. B.A.R., Oxford. B.A.R. International Series 1115

Busk, G., 1864. Pithecoid Priscan Man from Gibraltar. The Reader 4, 109-10.

Campmas, E., Amani, F., Morala, A., Debénath, A., El Hajraoui, M.A., Nespoulet, R., 2016. Initial insights into Aterian hunter-gatherer settlements on coastal landscapes: The example of Unit 8 of El Mnasra Cave (Temara, Morocco). Quaternary International 413, 5-20.

Campmas, E., Michel, P., Costamagno, S., Amani, F., Stoetzel, E., Nespoulet, R., El Hajraoui, M.A., 2015. Were Upper Pleistocene human/non-human predator occupations at the Témara caves (El Harhoura 2 and El Mnasra, Morocco) influenced by climate change? Journal of Human Evolution 78, 122-143.

Carrión García, J.S., 1992. Late quaternary pollen sequence from Carihuela Cave, southern Spain. Review of Palaeobotany and Palynology 71 (1-4), 37-77. doi:10.1016/00346667(92)90157-C. 
Carrión García, J.S., Munuera, M., Navarro, C., 1998. The palaeoenvironment of Carihuela Cave (Granada, Spain): A reconstruction on the basis of palynological investigations of cave sediments. Review of Palaeobotany and Palynology 99 (3-4), 317-40. doi:10.1016/S0034-6667(97)00040-7.

Clark, G., 1969. World prehistory: a new outline. Cambridge University Press, London. Available from: http://worldcatlibraries.org/wcpa/oclc/13175.

Collina-Girard, J., 2001. L'Atlantide devant le détroit de Gibraltar? Mythe et géologie. Comptes Rendus de l'Académie des Sciences - Series IIA - Earth and Planetary Science 333 (4), 233-40. doi:10.1016/S1251-8050(01)01629-9.

Collina-Girard, J., Bouzouggar, A., 2013. La longue préhistoire des brassages culturels en Méditerranée. In: Hassani-Idrissi, M. (Ed.), Méditerranée: Une histoire à partager, 29-57. Bayard, Montrouge.

Colonese, A.C., Mannino, M.A., Bar-Yosef Mayer, D.E., Fa, D.A., Finlayson, C., Lubell, D., Stiner, M.C., 2011. Marine mollusc exploitation in Mediterranean prehistory: An overview. Quaternary International 239 (1-2), 86-103. doi:10.1016/j. quaint.2010.09.001.

Corchón Rodríguez, M.S., 2004. Europa 16.500 - 14.000 a.C. un lenguaje común. In: Arias Cabal, P., Ontañón, R.P. (Eds.), La materia del lenguaje prehistórico: El arte mueble paleolítico de Cantabria en su contexto, 105-26. Gráficas Calima, Santander.

Cortés Sánchez, M. (Ed.), 2007a. Cueva Bajondillo (Torremolinos): Secuencia cronocultural y paleoambiental del cuaternario reciente en la Bahía de Málaga. Servicio de Publicaciones, Centro de Ediciones de la Diputación de Málaga, Málaga.

Cortés Sánchez, M., 2007b. El Paleolítico medio y superior en el sector central de Andalucía (Córdoba y Málaga). Monografías 22. Monterreina.

Cortés Sánchez, M., Jiménez Espejo, F.J., Rodríguez Vidal, J., Morales Muñiz, A., Simón Vallejo, M.D., 2012. Primeras ocupaciones humanas y fase antigua del Paleolítico medio meridional ibérico en la Bahía de Málaga. Mainake 33, 63-82.

Cortés Sánchez, M., Morales Muñiz, A., Simón-Vallejo, M.D., Lozano-Francisco, M.C., Vera-Peláez, J.L., Finlayson, C., Rodríguez Vidal, J., Delgado-Huertas, A., Jiménez-Espejo, F.J., Martínez-Ruiz, F., Martínez-Aguirre, M.A., Pascual-Granged, A.J., Bergadà-Zapata,M.M., Gibaja-Bao, J.F., Riquelme-Cantal, J.A., López-Sáez, J.A., Rodrigo-Gámiz, M., Sakai, S., Sugisaki, S., Finlayson, G., Fa, D.A., Bicho, N.F., 2011. Earliest Known Use of Marine Resources by Neanderthals. PLoS ONE 6 (9), e24026. doi:10.1371/journal.pone.0024026.

Cosson, J.-F., Hutterer, R., Libois, R., Sara, M., Taberlet, P., Vogel, P., 2005. Phylogeographical footprints of the Strait of Gibraltar and Quaternary climatic fluctuations in the western Mediterranean: a case study with the greater white-toothed shrew, Crocidura russula (Mammalia: Soricidae). Molecular Ecology 14 (4), 1151-62. doi:10.1111/j.1365-294X.2005.02476.x.

Currant, A.P., Fernández Jalvo, Y., Price, C., 2012. The large mammal remains from Vanguard Cave. In: Barton, N.E. (Ed.), Neanderthals in context: A report of the 1995-1998 excavations at Gorham's and Vanguard Caves, Gibraltar,141-50. Monograph / Oxford University School of Archaeology 75. Oxford University School of Archaeology, Oxford.

Cusick, J.G., 1998. Studies in culture contact: Interaction, culture change, and archaeology. Southern Illinois University Press edition. Occasional paper / Center for Archaeological Investigations, Southern Illinois University, Carbondale no. 25.
D'Errico, F., Vanhaeren, M., Barton, N.E., Bouzouggar, A., Mienis, H., Richter, D., Hublin, J.J., McPherron, Sh.,P., Lozouet, P., 2009. Additional evidence on the use of personal ornaments in the Middle Paleolithic of North Africa. Proceedings of the National Academy of Sciences 106 (38), 16051-16056.

D’Errico, F., Zilhão, J., Julien, M., Baffier, D., Pelegrin, J., 1998. Neanderthal Acculturation in Western Europe? A Critical Review of the Evidence and Its Interpretation. Current Anthropology 39 (S1), S1-S44. doi:10.1086/204689.

Delagnes, A., Meignen, L., 2006. Diversity of lithic production systems during the Middle Paleolithic in France: are there any chronological trends? In: Hovers, E., Kuhn, S.L. (Eds.), Transitions before the transition: Evolution and stability in the Middle Paleolithic and Middle Stone Age, 85-108. Interdisciplinary Contributions to Archaeology. Springer, New York.

Dibble, H.L., Aldeias, V., Álvarez Fernández, E., Blackwell, B., Hallett-Desguez, E., Jacobs, Z., Goldberg, P., Lin, S.C., Morola, A., Meyer, M.C., Olszewski, D.I., Reed, K., Reed, D., Rezek, Z., Richter, D., Roberts, R.G., Sandgathe, D., Schurmans, U., Skinner, A.R., Steele, T.E., El-Hajraoui, M., 2012. New excavations at the site of Contrebandiers Cave, Morocco. PaleoAnthropology 2012, 145-201.

Dodge, D.R., 2012. A molecular approach to Neanderthal extinction. Quaternary International 259, 22-32.

Doerschner, N., Fitzsimmons, K.E., Ditchfield, P., McLaren, S.J., Steele, T.E., Zielhofer, Ch., McPherron, Sh.P., Bouzouggar, A., 2016. A new chronology for Rhafas, northeast Moroc$\mathrm{co}$, spanning the North African Middle Stone Age through to the Neolithic. PLoS ONE 11 (9), e0162280.

Eiwanger, J., Mikdad, A., Moser, J., Nami, M., 2012. Découverte de coquilles perforées de type Nassarius au site Ifri n'Ammar (Rif Oriental, Maroc). Bulletin d'Archéologie Marocaine 22, 9-15.

Eriksson, A., Manica, A., 2012. Effect of ancient population structure on the degree of polymorphism shared between modern human populations and ancient hominins. Proceedings of the National Academy of Sciences 109 (35), 13956-60. doi:10.1073/pnas.1200567109.

Fendl, E., 1993. Mitgenommen: das Gepäck der Heimatvertriebenen. Jahrbuch für ostdeutsche Volkskunde 36, 229-43.

Fernández, J.R., López, R.A., España, M.B., 2001. Materiales arqueológicos de la Cueva del Humo (La Araña, Málaga). In: Junta de Andalucía (Ed.), Anuario Arqueológico de Andalucía [1998]: Sumario, Actividades Sistemáticas, Actividades de Urgencia, Consejería de Cultura, 540-49. Junta de Andalucía, Sevilla.

Fernández, S., Fuentes N., Carrión, J.S., González-Sampériz, P., Montoya, E., Gil, G., Vega-Toscano, G., Riquelme, J.A., 2007. The Holocene and Upper Pleistocene pollen sequence of Carihuela Cave, southern Spain. Geobios 40 (1), 75-90. doi:10.1016/j.geobios.2006.01.004.

Fernández Peris, J., 2007. La Cova del Bolomor (Tavernes de la Valldigna, Valencia): Las industrias líticas del pleistoceno medio en el ámbito del Mediterráneo peninsular. Serie de trabajos varios n. 108. Valencia: Servicio de Investigación Prehistórica, Diputación Provincial de Valencia.

Finlayson, C., Fa, D.A., Jiménez Espejo, F.J., Carrión García, J.S., Finlayson, G., Pacheco, F.G., Rodríguez Vidal, J., Stringer, Ch.B., Martínez Ruiz, F., 2008. Gorham's Cave, Gibraltar: The persistence of a Neanderthal population. Quaternary International 181, 64-71.

Floss, H. (Ed.), 2013. Steinartefakte vom Altpaläolithikum bis in die Neuzeit. 2nd ed., Kerns, Tübingen. 
Foley, R., Lahr, M.M., 1997. Mode 3 Technologies and the Evolution of Modern Humans. Cambridge Archaeological Journal 7 (01), 3. doi:10.1017/S0959774300001451.

Fontugne, M., Reyss, J.L., Hublin, J.J., Ruiz, C.B., Lara, P.M., 1995. The Mousterian site of Zafarraya (Andalucia, Spain): Dating and implications on the palaeolithic peopling processes of Western Europe. Comptes Rendus de l'Académie des Sciences - Series IIA - Earth and Planetary Science 321 (10), 931-37.

Garcea, E., 2004. Crossing deserts and avoiding seas: Aterian North African-European relations. Journal of Anthropological Research 60 (1), 27-53.

Garcia Sanchez, M., Tillier, A.M., Garralda, M.D., Vega Toscano, L.G., 1994. Les dents d'enfant des niveaux moustériens de la grotte de Carihuela (Grenade-Espagne). Paléo 6 (1), 79-88. doi:10.3406/pal.1994.1080.

Garralda, M.D., 2005. Los Neandertales en la Península Ibérica. Munibe Antropologia-Arkeologia 57, 289-314.

Garralda, M.D., Galván, B., Hernandez, C.M., Mallol, C., Gomez, J.A., Maureille, B., 2014. Neanderthals from El Salt (AIcoy, Spain) in the context of the latest Middle Palaeolithic populations from the southeast of the Iberian Peninsula. Journal of Human Evolution 75, 1-15.

Gehlen, A., 1986. Der Mensch: Seine Natur und seine Stellung in der Welt. Aula, Wiesbaden.

Hublin, J.J., Ben-Ncer, A., Bailey, S.E., Freidline, S., Neubauer, S., Skinner, M.M., Bergmann, I., Le

Cabec, A., Benazzi, S., Harvati, K., Gunz, P., 2017. New fossils from Jebel Irhoud, Morocco and the pan-African origin of Homo sapiens. Nature 546, 289-292.

Hublin, J.J., Tillier, A.M., Tixier, J., 1987. L'humérus d'enfant moustérien (Homo 4) du Djebel Irhoud (Maroc) dans son contexte archéologique. Bulletins et Mémoires de la Société d'Anthropologie de Paris 4 (2), 115-41. doi:10.3406/bmsap.1987.1625.

Lovita, R., 2011. Shape Variation in Aterian Tanged Tools and the Origins of Projectile Technology: A Morphometric Perspective on Stone Tool Function. PLoS ONE 6 (12), e29029. doi:10.1371/journal. pone.0029029.

Jennings, R.P., Finlayson, C., Fa, D.A., Finlayson, G., 2011. Southern Iberia as a refuge for the last Neanderthal populations. Journal of Biogeography 38 (10), 1873-85. doi:10.1111/ j.1365-2699.2011.02536.x.

Jennings, R.P., Giles Pacheco, F., Barton, N.E., Collcutt, S.N., Gale, R., Gleed-Owen, C.P., Gutierrez Lopez, J.M., Higham, T.F.G., Parker, A., Price, C., Rhodes, E., Santiago Pérez, A., Schwenninger, J.L., Turner, E., 2009. New dates and palaeoenvironmental evidence for the Middle to Upper Palaeolithic occupation of Higueral de Valleja Cave, southern Spain. Quaternary Science Reviews 28 (9-10), 830-39. doi:10.1016/j. quascirev.2008.11.014.

Jerardino, A., Marean, C.W., 2010. Shellfish gathering, marine paleoecology and modern human behavior: Perspectives from cave PP13B, Pinnacle Point, South Africa. Journal of Human Evolution 59 (3-4), 412-24. doi:10.1016/j.jhevol.2010.07.003.

Kehl, M., Burow, Ch., Cantalejo, P., Domínguez-Bella, S., Durán, J.J., Henselowsky, F., Klasen, N., Linstädter, J., Medianero, J., Pastoors, A., Ramos, J., Reicherter, K., Schmidt, Ch., Weniger, G.C., 2016. Site formation and chronology of the new Paleolithic site Sima de Las Palomas de Teba, southern Spain. Quaternary Research 85 (2), 313-31. doi:10.1016/j. yqres.2016.01.007.
Kuhn, S.L., Bouzouggar, A., Fernandez, Ph., 2015. Excavations at Bizmoune Cave (Essaouira): first findings on the Aterian on the south Atlantic coast of Morocco. Paleoanthropology Society 2015 Annual Meeting (April 14), 15

La Torre Sáinz, I. de, Martínez Moreno, J., Mora Torcal, R., 2013. Change and Stasis in the Iberian Middle Paleolithic. Current Anthropology 54 (S8), S320-S336. doi:10.1086/673861.

Lalueza Fox, C., Rosas González, A., Estalrrich, A., Gigli, E., Campos, P.E., Garcia Tabernero, A., Garcia Vargas, S., Sánchez-Quinto, F., Ramírez, O., Civit, S., Bastir, M., Huguet, R., Santamaría, D., Gilbert, M.T.P., Willerslev, E., de la Rasilla, M., 2011. Genetic evidence for patrilocal mating behavior among Neandertal groups. Proceedings of the National Academy of Sciences 108 (1), 250-53. doi:10.1073/pnas.1011553108.

Lenssen-Erz, T., Linstädter, J., 2009. Towards a methodology of landscape archaeology. In: Bollig, M., Bubenzer, O. (Eds.), African landscapes: interdisciplinary approaches, 159-98, Springer, New York.

Linstädter, J., Eiwanger, J., Mikdad, A., Weniger, G.C., 2012. Human occupation of Northwest Africa: A review of Middle Palaeolithic et Epipalaeolithic sites in Morocco. Quaternary International 274, 158-74.

Marean, C.W., 2011. Coastal South Africa and the co-evolution of the modern human lineage and the coastal adaptation. In: Bicho, N.F., Haws, J.A., Davis, L.G. (Eds.), Trekking the Shore, 421-40. Springer, New York.

Marean, C.W., Bar-Matthews, M., Bernatchez, J., Fisher, E., Goldberg, P., Herries, A.I.R., Jacobs, Z., Karkanas, P., Minichillo, T., Nilssen, P.J., Thompson, E., Watts, I., Williams, H.M., 2007. Early human use of marine resources and pigment in South Africa during the Middle Pleistocene. Nature 449 (7164): 905-908. doi:10.1038/nature06204.

Maslow, A., 1943. A theory of human motivation. Psychological Review 50 (4), 370. doi:10.1037/h0054346.

Maslow, A., 1970. Motivation and personality. Harper \& Row, New York

Maslow, A., 1981. Motivation und Persönlichkeit. Rowohlt, Reinbeck.

McBreaty, S., Brooks, A.S., 2000. The revolution that wasn't: a new interpretation of the origin of modern human behavior. Journal of Human Evolution 39, 453-563.

Mellars, P., Boyle, K.V., Bar-Yosef, O., Stringer, Ch.B. (Eds.), 2007. Rethinking the human evolution. McDonald Institute for Archaeological Research, Cambridge.

Miller, D.W., 2011. Searching for a new world: The background and baggage of scots-irish immigrants. In: Hofstra, W.R. (Ed.), Ulster to America: The Scots-Irish Migration Experience, 16801830, 1-23. The University of Tennessee Press.

Monchot, H., Aouraghe, H., 2009. Deciphering the taphonomic history of an Upper Paleolithic faunal assemblage from Zouhrah Cave/El Harhoura 1, Morocco. Quaternaire 20 (2), 23953. doi: $10.4000 /$ quaternaire.5166.

Mora Torcal, R., de La Torre Sáinz, I., Martínez Moreno, J., 2004. Middle Palaeolithic mobility and land use in the southwestern Pyrenees: The example of level 10 in La Roca dels Bous (Noguera, Catalunya, Northeast Spain). In: Conard, N.J. (Ed.), Settlement dynamics of the Middle Paleolithic and Middle Stone Age, 415-36. Kerns, Tübingen.

Nami, M., Moser, J., 2010. La Grotte d'Ifri n'Ammar: Le Paléolithique Moyen. Reichert, Wiesbaden. 
Navazo, M., Colina, Á., Domínguez-Bella, S., Benito-Calvo, A., 2008. Raw stone material supply for Upper Pleistocene settlements in Sierra de Atapuerca (Burgos, Spain): Flint characterization using petrographic and geochemical techniques. Journal of Archaeological Science 35 (7), 1961-73. doi:10.1016/j. jas.2007.12.009.

Navazo, M., Diez Fernández-Lomana, C., Torres, T., Colina, Á., Ortiz, J.E., 2005. La cueva de Prado Vargas. Un yacimiento del Paleolítico Medio en el sur de la Cordillera Cantábrica. In: Montes Barquín, R., Lasheras Corruchaga, J.A. (Eds.), Neandertales Cantábricos, estado de la cuestión, edited by Ramón and José A., 151-66. Santander. Monografías 20.

Nespoulet, R., Debénath, A., El Hajraoui, M.A., Michel, P., Campmas, E., Oujaa, A., Ben-Ncer, A., Lacombe, J.P., Amani, F., Stoetzel, E., Boudad, L., 2008. Le contexte archéologique des restes humains Atériens de la région de Témara (Maroc): Apport des fouilles des grottes d'El Mnasra et d'El Harhoura 2. Actes RQM (4), 356-75.

Otte, M., 2013. L'extension africaine en Europe méridionale: Le Solutréen. Espacio Tiempo y Forma. Serie I, Prehistoria y Arqueología 1(5). doi:10.5944/etfi.5.2012.9272.

Pastoors, A., 2009. Blades? - Thanks, no interest! NeanderthaIs in Salzgitter-Lebenstedt. Quartär 56, 105-18.

Pastoors, A., Tafelmaier, Y., 2010. Bladelet production, core reduction strategies, and efficiency of core configuration at the Middle Palaeolithic site Balver Höhle (North Rhine Westphalia, Germany). Quartär 57, 25-41.

Patou Mathis, M., 2000. Neanderthal subsistence behaviours in Europe. International Journal of Osteoarchaeology 10 (5), 379-95. doi:10.1002/1099-1212(200009/10)10:5<379:AIDOA558>3.0.CO;2-4.

Peresani, M., Fiore, I., Gala, M., Romandini, M., Tagliacozzo, A., 2011. Late Neandertals and the intentional removal of feathers as evidenced from bird bone taphonomy at Fumane Cave 44 ky B.P., Italy. Proceedings of the National Academy of Sciences 108 (10), 3888-93. doi:10.1073/pnas.1016212108.

Ramos-Fernandéz, J., Aguilera, R., Cortés, M., Bañares, M., 2003. La Prehistoria en la franja costera de la Bahía de Málaga: El complejo kárstico de La Araña (Málaga, España). Pliocénica 3, 117-30.

Ramos-Muñoz, J., 2013. Relationships and contacts of the Pleistocene hunter-gatherer societies with Mode III technology between northern Africa and the southern Iberian Peninsula. In: Pastoors, A., Auffermann, B. (Eds.), Pleistocene foragers on the Iberian Peninsula: Their culture and environment: Festschrift in honour of Gerd-Christian Weniger for his sixtieth birthday, 35-54. Neanderthal Museum, Mettmann. Wissenschaftliche Schriften des Neanderthal Museums 7.

Ramos-Muñoz, J., Bernal-Casasola, D., Barrena-Tocino, A. Domínguez-Bella, S., Clemente-Conte, I., Vijande-Vila, E., Cantillo-Duarte, J.J., Almisas-Cruz, S., 2016. Middle Palaeolithic Mode 3 lithic technology in the rock-shelter of Benzú (North Africa) and its immediate environmental relationships. Quaternary International 413 (Part A), 21-35.

Ramos-Muñoz, J., Bernal-Casasola, D., Domínguez-Bella, S., Clemente-Conte, I., Barrena-Tocino, A., Vijande-Vila, E., CantiIlo-Duarte, J.J., 2014. Die mittelpaläolithische Steingerätetechnologie des Modus 3 im Abri Benzú (Nordafrika). Quartär 61, 7-21.

Ramos-Muñoz, J., Domínguez-Bella, S., Cantillo-Duarte, J.J., Soriguer, M., Pérez, M., Hernando, J., Vijande-Vila, E., Zabala, C., Clemente-Conte, I., Bernal-Casasola, D., 2011. Marine resources exploitation by Palaeolithic hunter-fisher-gatherers and Neolithic tribal societies in the historical region of the Strait of Gibraltar. Quaternary International 239 (1-2), 104-113. doi:10.1016/j.quaint.2011.03.015.
Richter, D., Moser, J., Nami, M., Eiwanger, J. Mikdad, A., 2010. New chronometric data from Ifri n'Ammar (Morocco) and the chronostratigraphy of the Middle Palaeolithic in the Western Maghreb. Journal of Human Evolution 59(6), 672-79. doi:10.1016/j.jhevol.2010.07.024.

Richter, D., Grün, R., Joannes-Boyau, R., Steele, T.E., Amani, F., Rué, M., Fernandes, P., Raynal, J.P., Geraads, D., BenNcer, A., Hublin, J.J., McPherron, Sh.P., 2017. The age of the hominin fossils from Jebel Irhoud, Morocco, and the origins of the Middle Stone Age. Nature 546, 293-296.

Ríos Garaizar, J., Eixea, A., Villaverde Bonilla, V., 2015. Ramification of lithic production and the search of small tools in Iberian Peninsula Middle Paleolithic. Quaternary International 361, 188-99.

Rodríguez Vidal, J., Caceres, L.M., Finlayson, C., Gracia, F.J., Martínez Aguirre, M.A., 2004. Neotectonics and shoreline history of the Rock of Gibraltar, southern Iberia. Quaternary Science Reviews 23 (18-19), 2017-29. doi:10.1016/j.quascirev.2004.02.008.

Rodríguez Vidal, J., D’Errico, F., Giles Pacheco, F., Blasco, R., Rosell, J., Jennings, R.P., Queffelec, A., Finlayson, G., Fa, D.A., Gutiérrez López, J.M., Carrión, J.S., Negro, J.J., Finlayson, S., Cáceres, L.M., Bernal, M.A., Fernández Jiménez, S., Finlaysone, C., 2014. A rock engraving made by Neanderthals in Gibraltar. Proceedings of the National Academy of Sciences 111 (37), 13301-13306. doi:10.1073/pnas.1411529111.

Salazar-García, D.C., Power, R.C., Serra, A.S., Villaverde Bonilla, V., Walker, M.J., Henry, A.G., 2013. Neanderthal diets in central and south eastern Mediterranean Iberia. Quaternary International 318, 3-18.

Sanchez Quinto, F., Botigue, L.R., Civit, S., Arenas, C., Avila-Arcos, M.C., Bustamante, C.D., Comas, D., Lalueza Fox, C., 2012. North African populations carry the signature of admixture with Neandertals. PLoS ONE 7 (10), e47765. doi:10.1371/ journal.pone.0047765.

Sanchis Serra, A., Fernández Peris, J., 2011. Nuevos datos sobre la presencia de lepus en el pleistoceno medio y superior del Mediterráneo Ibérico: La Cova del Bolomor (Valencia). SAGVNTVM. Papeles del Laboratorio de Arqueología de Valencia 43, 9-20. doi:10.7203/SAGVNTVM.43.346.

Santonja Gómez, M., Pérez González, A., Panera, J., Rubio Jara, S., Méndez Quintas, E., 2016. The coexistence of Acheulean and Ancient Middle Palaeolithic techno-complexes in the Middle Pleistocene of the Iberian Peninsula. Quaternary International 411, Part B, 367-77.

Santonja Gómez, M., Villa, P., 2006. The Acheulean of Western Europe. In: Inbar, N.G., Sharon, G. (Eds.), Axe age: Acheulian tool-making from quarry to discard, 429-78. Equinox, London.

Scerri, E.M.L., 2013a. On the spatial and technological organisation of hafting modifications in the North African Middle Stone Age. Journal of Archaeological Science 40(12), 4234-48. doi:10.1016/j.jas.2013.06.011.

Scerri, E.M.L., 2013b. The Aterian and its place in the North African Middle Stone Age. Quaternary International 300, 111-130.

Scerri, E.M.L., Drake, N.A., Jennings, R., Groucutt, H.S., 2014. Earliest evidence for the structure of Homo sapiens populations in Africa. Quaternary Science Reviews 101, 207-16.

Sharon, G., 2011. Flakes Crossing the Straits? Entame Flakes and Northern Africa-lberia Contact During the Acheulean. African Archaeological Review 28(2), 125-40. doi:10.1007/ s10437-011-9087-3. 
Shipton, C., Clarkson, Ch., Bernal, M.A., Boivin, N., Finlayson, C., Finlayson, G., Fa, D.A., Pacheco, F.G., Petraglia, M.D., 2013. Variation in Lithic Technological Strategies among the Neanderthals of Gibraltar. PLoS ONE 8 (6), e65185. doi:10.1371/journal. pone.0065185.

Simón Vallejo, M., Cortés Sánchez, M., 2007. El aprovisionamiento y la gestión de las materias primas líticas. In: Cortés Sánchez, M. (Ed.), Cueva Bajondillo (Torremolinos): Secuencia cronocultural y paleoambiental del cuaternario reciente en la Bahía de Málaga, 467-78. Servicio de Publicaciones, Centro de Ediciones de la Diputación de Málaga, Málaga.

Smith, T.M., Tafforeau, P., Reid, D.J., Grün, R., Eggins, S., Boutakiout, M., Hublin, J.J., 2007. Earliest evidence of modern human life history in North African early Homo sapiens. Proceedings of the National Academy of Sciences 104 (15), 6128-33. doi:10.1073/pnas.0700747104.

Soriano, S., Villa, P., Wadley, L., 2007. Blade technology and tool forms in the Middle Stone Age of South Africa: the Howiesons Poort and post-Howiesons Poort at Rose Cottage Cave. Journal of Archaeological Science 34, 681-703.

Spinapolice, E.E., Garcea, E.A.A., 2014. Aterian lithic technology and settlement system in the Jebel Gharbi, North-Western Libya. Quaternary International 350, 241-53.

Steele, T.E., Álvarez Fernández, E., 2011. Initial Investigations into the Exploitation of Coastal Resources in North Africa During the Late Pleistocene at Grotte des Contrebandiers, Morocco. In: Bicho, N.F., Haws, J.A., Davis, L.G. (Eds.), Trekking the Shore, 383-403. Springer, New York.

Stein, G.J., 2002. From Passive Periphery to Active Agents: Emerging Perspectives in the Archaeology of Interregional Interaction. American Anthropologist 104(3), 903-916. doi:10.1525/aa.2002.104.3.903.

Stoetzel, E., Campmas, E., Michel, P., Bougariane, B., Ouchaou, B., Amani, F., El Hajraoui, M.A., Nespoulet, R., 2014. Context of modern human occupations in North Africa: Contribution of the Témara caves data. Quaternary International 320, 143-61.

Straus, L.G., 2001. Africa and Iberia in the Pleistocene. Quaternary International 75 (1), 91-102.

Stringer, Ch.B., Finlayson, C., Barton, N.E., Fernández Jalvo, Y., Cáceres, I., Sabin, R.C., Rhodes, E.J., Currant, A. P., Rodríguez-Vidal, J., Giles-Pacheco, F., Riquelme-Cantal, J.A., 2008. Neanderthal exploitation of marine mammals in Gibraltar. Proceedings of the National Academy of Sciences 105 (38), 14319-24. doi:10.1073/pnas.0805474105.

Texier, J.P.,1986. Le site atérien du Chaperon-Rouge (Maroc) et son contexte géologique. Bulletin d'Archélogie Marocaine 16, 27-74.

The Editors of Encyclopædia Britannica, 2016. "Culture contact." https://www. britannica.com/topic/culture-contact.

Tixier, J., 1967. Procédés d'analyse et questions de terminologie dans l'étude des ensembles industriels du Paléolithique récent et de l'Epipaléolithique en Afrique du Nord-Ouest. In: Bishop, W.W., Clark, J.D. (Eds.), Background to evolution in Africa, 771-820. University of Chicago Press, Chicago.

Torres Navas, C., Baena Preysler, J., Morgado Rodríguez, A., Lozano Rodríguez, J.A., Alcaraz Castaño, M., 2012. Un enclave solutrense en las Cordilleras Béticas occidentales: La Cueva del Higueral-Guardia (Cortes de la Frontera, Málaga, España). Espacio Tiempo y Forma. Serie I, Prehistoria y Arqueología 5, 223-33.
Vanhaeren, M., d'Errico, F., van Niekerk, K.L., Henshilwood, Ch.S., Erasmus, R.M., 2013. Thinking strings: Additional evidence for personal ornament use in the Middle Stone Age at Blombos Cave, South Africa. Journal of Human Evolution 64 (6), 500-517. doi:10.1016/j.jhevol.2013.02.001.

Vega Toscano, L.G., 1988. El Paleolítico Medio del Sureste español y Andalucía Oriental. Dissertation, Complutense.

Walker, M.J., Gibert, J., López, M.V., Lombardi, A.V., Pérez-Pérez, A., Zapata, J., Ortega, J., Higham, T.F.G., Pike, A., Schwenninger, J.L., Zilhão, J., Trinkaus, E., 2008. Late Neandertals in Southeastern Iberia: Sima de las Palomas del Cabezo Gordo, Murcia, Spain. Proceedings of the National Academy of Sciences 105 (52), 20631-36. doi:10.1073/pnas.0811213106.

Walker, M.J., López Martínez, M.V., Ortega-Rodrigáñez, J., Haber Uriarte, M., López Jiménez, A., Avilés-Fernández, A., Polo-Camacho, J.L. 2012. The excavation of buried articulated Neanderthal skeletons at Sima de las Palomas (Murcia, SE Spain). Quaternary International 259, 7-21.

Wengler, L., 1997. La transition du Moustérien à l'Atérien. L'Anthropologie 101 (3), 448-81.

White, R., 2001. Personal ornaments from the Grotte du Renne at Arcy-sur-Cure. Athena Review 2, 41-46.

Will, M., Parkington, J.E., Kandel, A.W., Conard, N.J., 2013. Coastal adaptations and the Middle Stone Age lithic assemblages from Hoedjiespunt 1 in the Western Cape, South Africa. Journal of Human Evolution 64 (6), 518-37. doi:10.1016/j.jhevol.2013.02.012.

Wood, R.E., Arrizabalaga, Á., Camps, M., Fallon, S., Iriarte Chiapusso, M.J., Jones, R., Maroto, J., de la Rasilla, M., Santamaría, D., Soler, J., Soler, N., Villaluenga, A.,Higham, T.F.G., 2014. The chronology of the earliest Upper Palaeolithic in northern Iberia: New insights from L'Arbreda, Labeko Koba and La Viña. Journal of Human Evolution 69, 91-109.

Wood, R.E., Barroso Ruiz, C., Caparrós, M., Pardo, J.F.J., Santos, B.G., Higham, T.F.G., 2013. Radiocarbon dating casts doubt on the late chronology of the Middle to Upper Palaeolithic transition in southern Iberia. Proceedings of the National Academy of Sciences 110 (8), 2781-86. doi:10.1073/ pnas. 1207656110

Zilhão, J., 2001. Middle Paleolithic settlement patterns in Portugal. In: Conard, N.J. (Ed.), Settlement dynamics of the Middle Paleolithic and the Middle Stone Age, 597-608. Kerns, Tübingen.

Zilhão, J., 2006. Chronostratigraphy of the Middle-to-Upper Paleolithic Transition in the Iberian Peninsula. Pyrenae 37 (1), 7-84.

Zilhão, J., 2012. Neandertals from World's End: results of recent research. Biodiversidad humana y Evolución, 68-77.

Zilhão, J., Ajas, A., Badal García, E., Burow, Ch., Kehl, M., López Sáez, J.A., Pimenta, C. 2016. Cueva Antón: A multi-proxy MIS 3 to MIS 5 a paleoenvironmental record for SE Iberia. Quaternary Science Reviews 146, 251-73.

Zilhão, J., Angelucci, D.E., Badal García, E., d'Errico, F., Daniel, F., Dayet, L., Douka, K., Higham, T.F.G.,

Martínez-Sánchez, M.J., Montes-Bernárdez, R., Murcia-Mascarós, S., Pérez-Sirvent, C., Roldán-García, C., Vanhaeren, M., Villaverde, V., Wood, R., Zapata, J. 2010. Symbolic use of marine shells and mineral pigments by Iberian Neandertals. Proceedings of the National Academy of Sciences 107 (3), 1023-28. doi:10.1073/pnas.0914088107. 
